SEFAD, 2017 (38): 1-22

e-ISSN: 2458-908X

\title{
Beyşehir'in Huğlu Kasabasında Yaşayan Türkmenlerin Belirgin Ağız Özellikleri
}

\author{
Okt. Dr. Ahmet Çal \\ Necmettin Erbakan Üniversitesi Seydişehir Meslek Yüksekokulu \\ ahmetcal42@gmail.com
}

Öz

Bir dilin tarihî gelişimini ve söz varlığını ortaya koyabilmek için ağız araştırmaları son derece önemlidir. Buna bağlı olarak Anadolu ve Rumeli ağızları ile ilgili son yıllarda birçok çalışma yapılmıştır. Bütün bu çalışmalara rağmen incelenmesi gereken daha pek çok bölge mevcuttur. Bu bölgelerden biri de Konya ili, Beyşehir ilçesine bağlı Huğlu kasabasıdır. Konya'nın güneybatısında yer alan 1.410 rakımlı ve 3.000 nüfuslu bu şirin kasabanın tarihi 70-80 yıl öncesine dayanmaktadır. Birbirine akraba iki sülaleden birinin Antalya'ya göç etmesi diğerinin de Huğlu'ya yerleşmesiyle kasabanın temelleri atılmıştır. Kendilerine özgü gelenekleri ve ağız özellikleri bulunan Huğlu'yla ilgili daha önce bir çalışma yapılmamış olması bir eksikliktir. Bu çalışmada, bu eksikliği gidermek için bölgede yaşayan Türkmenlerin ağızları incelenmiştir. Kasabada yaşayan çeşitli yaş gruplarındaki kaynak şahıslardan derlenen metinlerden hareketle bölge ağzının fonetik ve morfolojik özellikleri tespit edilmeye çalışılmıştır.

Anahtar Kelimeler: Ağız araştırması, Huğlu (Beyşehir/Konya), Türkmen ağızları, dil özellikleri.

\section{The Dialect Characteristics of the Turkmenians Living in the Town of Huğlu of Beyşehir}

\begin{abstract}
Dialect research is extremely important in order to reveal the historical development and vocabulary of a language. Accordingly, a number of studies have been carried out in recent years about the dialects of Anatolia and Rumeli. Despite all of these studies, there are many more areas that need to be examined. One of these regions is the town of Huğlu in the Beyşehir district of Konya province. The history of this charming town with an altitude of 1,410 and a population of 3,000, located on the southwest of Konya, dates back 70-80 years. The fact that one of the two relative families migrated to Antalya and the other settled in Huğlu lay the foundations of the town. It is a shortcoming that there is no previous work on Huğlu, which has its own traditions and dialectical features. In this study, the dialect of the Turkmenians living in the region was examined. The phonetic and morphological features of the region have been determined by using the texts compiled from source persons in various age groups living in the town.
\end{abstract} features.

Keywords: Dialect research, Huğlu (Beyşehir / Konya), Turkmenian dialects, language

Gönderim Tarihi / Sending Date: 28/09/2017 Kabul Tarihi / Acceptance Date: 14/11/2017 


\section{GİRIŞ}

Ağız araştırmaları, dil bilimi içerisinde önemli bir yere sahiptir. Türkçe için ağız araştırmalarının başlangıcını, net bilgiler olmamakla birlikte, Kaşgarlı Mahmud'a kadar götürebiliriz (Gemalmaz 1999: 5). Anadolu ağızları üzerine yapılan araştırmalar, 19. yüzyılın ortalarında yabancı araştırmacıların eserleriyle başlayan bu alana, 1940 yılından sonra yerli araştırmacılar da yönelmiştir. Ağız çalışmalarıyla ilgili ilk sınıflandırma denemesi İ. Kúnos'a aittir (Karahan 1996: IX). Türkiye' de ise ağız araştırmaları ciddi anlamda Ahmet Caferoğlu ile başlamış ve uzun yıllar onun öncülüğünde devam etmiştir (Gülensoy 1999: 16). Son dönemde çok sayıda ağız çalışması yapılmış olmasına rağmen daha araştırılması gereken birçok bölge vardır. Bu bölgelerden biri de Konya ili Beyşehir ilçesine bağlı Huğlu kasabasıdır.

Konya'nın güneybatısında yer alan, Konya'ya yaklaşık 130, Beyşehir'e yaklaşık 35 km uzaklıkta bulunan Huğlu kasabasında temel geçim kaynağı tüfekçiliktir. Kasabadaki tüfek fabrikasında üretilen tüfekler yurt içi ve yurt dışına ihraç edilmektedir. Nüfusun \% 80 'i geçimini tüfek yapımından sağlamaktadır. Geriye kalan kesim ise ticaretle uğraşmaktadır. Bölgenin engebeli olması ve tarım alanlarının çok az olması nedeniyle tarım yok denecek kadar azdır. Öyle ki kasabada hemen hemen hiç traktör yoktur. Hayvancılık, eskiden önemli bir geçim kaynağı iken son yıllarda çok azalmıştır. Tarihi 70-80 yıl öncesine dayanan bölgenin kendine has ağız özellikleri mevcuttur. Öyle ki Beyşehir ve çevresinde bir kişinin konuşmasına bakarak onun Huğlulu olup olmadığını anlamak mümkündür. Bölge ağzının daha çok Türkmenlerin dil özelliklerini yansıttığını söyleyebiliriz.

$\mathrm{Bu}$ çalışmada, bölgede yaşayan Türkmenlerin ağızlarının standart Türkiye Türkçesinden ayrılan fonetik ve morfolojik özellikleri tespit edilmeye çalışılmıştır.

Derlenen metinlerin yazıya aktarılmasında kullanılan çeviri yazı işaretleri şunlardır:

: $\quad$ Kendisinden önceki ünlünün uzun olduğunu gösterir.

ç Süreksiz, yarı tonlu, diş eti ünsüzü (/c/-/ç/arası).

è Kapalı /e/ ünlüsü (/e/-/i/ arası).

g Süreksiz, tonlu, art damak ünsüzü.

h Sürekli, arka damak ünsüzü.

h $\quad$ Erimek üzere olan $/ \mathrm{h} /$ ünsüzü.

k $\quad$ Patlayıc1, tonsuz art damak ünsüzü.

ḱ Süreksiz, yarı tonlu art damak ünsüzü $(/ \mathrm{k} /-/ \dot{g} /$ arası).

k Süreksiz, yarı tonlu ön damak ünsüzü $(/ \mathrm{k} /-/ \mathrm{g} /$ arası).

ñötümlü, damaksıl /n/ ünsüzü.

ó Yuvarlak, geniş, yarı art ünlü (/o/-/ö/ arası).

ṕ Süreksiz, yarı tonlu ünsüz (/p/-/b/ arasi).

s Tonsuz, diş ünsüzü (/ş/-/ç/ arası).

$\mathfrak{t} \quad$ Süreksiz, yarı tonlu diş eti ünsüzü (/t/-/d/ arası).

ú Yuvarlak, dar, yarı art ünlü (/u/-/ü/ arası).

y Erimek üzere olan $/ y /$ ünsüzü.

_ $\quad$ İkili ünlü işareti.

Ulama işareti.

$\sim \quad$ Varyasyon işareti. 


\section{FONETİK ÖZELLİKLER}

Ses bilgisi ağız çalışmalarında önemli bir yer tutmaktadır. Zira ağız araştırmalarında standart yazı dilinden farklı olarak yerel konuşma dilleri dikkate alındığından çok sayıda sesle ve farklı yapılarla karşılaşılabilmektedir. Ancak bu ses ve yapıların çoğu ara seslerdir. Bu yüzden fonolojik görevleri yoktur. (Küçükballı-Yastı 2014: 456-457). Çalışmamızın temelini oluşturan Beyşehir ilçesi Huğlu kasabası Türkmen ağzında Türkiye Türkçesi standart yazı dilinde bulunan seslerden farklı olarak tespit edilen sesler kapalı /e/ ünlüsü ve damak ünsüzü /n/'dir.

\section{1. Ünlüler}

\subsubsection{Kapalı e (/è/) Ünlüsü}

Kapalı /e/ dil sırtının i'ye nazaran biraz daha geride kabarması ile teşkil edilir (Korkmaz 1994: 5). Türkçede kapalı /e/ ünlüsünün varlığı eskiden beri tartışılmaktadır. Bu sesin varlığ tarihî metin çalışmalarında da her zaman tartışma konusu olmuştur. İslamiyet'in kabulünden sonra kullanılan Arap alfabesinde ünlülerin elif, vav, ye ile gösterilmesi kapalı /e/'nin tespitini daha da zorlaştırmıştır. (Erdem-Gül 2006: 111). Ancak kapalı /e/ sesi tarihî metinler incelendiğinde yazı dilinde varlığını bir şekilde hissettirmiştir (Yavuz 1991: 271-306). Bundan dolayı tam olarak kesinleşmemiş olsa da dilbilimciler tarafından Türkçenin asli sesleri arasında gösterilmektedir (Yılmaz 1991: 151-156). Batı Anadolu ağızlarında bazı yöreler hariç kapalı /e/ ünlüsünün anlam ayırıcı olmaktan ziyade sanki bir ara ses olduğu tespit edilir. (Erdem-Gül 2006: 111). Huğlu kasabası ağız özellikleri incelendiğinde genellikle kök hecede görev yapan kapalı /e/ sesinin çeşitli ses olayları sonucu kök hecenin dışındaki hecelerde de örneklerine rastlanmıştır.

\subsubsection{Türkçe Kelimelerin Kök Hecesinde Bulunduğu Örnekler}

Derlediğimiz metinlerde karşımıza çıkan kök hecesinde kapalı /e/ sesinin bulunduğunu tahmin ettiğimiz sözcüklerden bazıları şunlardır: de-, git-, iyi, et-, ne, iş, yeni, ver-, giy-, yedi, yer, beş, yiyecek, geri.

kız eviñe gèdelle: / Kız evine giderler. (EÖ)

direk ġı evine gèdeyo: / Direkt kız evine gidiyor. (EK)

esgiden dörd bẻş odu yoğudu. / Eskiden dört beş oda yoktu. (FS)

\subsubsection{Yabancı Dillerden Geçen Sözcüklerde Kullanıldığı Örnekler}

Yaptığımız incelemede Türkçe kelimelerdeki kadar fazla olmamakla birlikte Arapça ve Farsçadan geçen birkaç kelimede de kapalı /e/ ünlüsünün kullanıldığı tespit edilmiştir.

dünkü soyuhda şėy olmuş payamlar üşümüş. / Dünkü soğukta şey olmuş bademler üşümüş. (<Farsça şey) (YA)

o cèviz yenir dụa alı: / O ceviz yenir, dua alır. (<Arapça cevz) (AD)

hayatımda en pėşman olduğum şeylerden biri... / Hayatımda en pişman olduğum şeylerden biri... (< Farsça peşîmân) (YA)

\subsubsection{Ses Olayları Sonucu Meydana Gelen Örnekler}

Derlediğimiz metinlerde ses olayları sonucu meydana gelen kapalı /e/ ünlüsü için sadece hèçbi ve bişèy örneklerini gösterebiliriz. Bu örneklerde dar ünlü olan /i/, gerileyici ve ilerleyici benzeşme yoluyla kendisinden önceki ve sonraki ünlüleri etkilemiştir. Anadolu ağızlarında ünlü incelmesi genel bir eğilimdir. Ünlüler üzerinde inceltici etkisi bulunan dişdamak ünsüzü "ç" ve ön damak ünsüzü /y/'nin aynı zamanda daraltıcı etkisi de bulunmaktadır (Sağır 2002: 2, 4). Hèçbi ve bişèy sözcüklerinde de bu etkiye bağlı olarak /e/ sesi, kapalı /e/'ye dönüşmüştür. 
okey, tavla: oyun düze:ni hèçbi zaman olmadı bizim köyde. / Okey, tavla oyun düzeni hiçbir zaman olmadı bizim köyde. (YA)

arjantine dünya gupası gazandırdı gendi imka:nñarıyla yani renkli bişėydi. / Arjantin'e dünya kupası kazandırdı kendi imkânlarıyla yani renkli bir şeydi. (YA)

\subsubsection{Uzun Ünlüler}

Beyşehir ilçesi Huğlu kasabası ağzında yabancı asıllı kelimelerin haricinde asli uzun ünlülere rastlanmamıştır. Metinlerde tespit edilen uzun ünlüler, ünsüz düşmesi, ünsüz erimesi, ünlü birleşmesi ve hece kaynaşması gibi çeşitli ses olayları sebebiyle uzamış olan ünlülerdir.

\subsubsection{1. Ünsüz Düşmesi Sebebiyle Oluşan İkincil Uzun Ünlüler}

Genellikle kelime içindeki / $/ \mathrm{g} /, / \mathrm{h} /, / \tilde{\mathrm{n}} /$, /y/ ve Arapça kökenli kelimelerdeki ayn seslerinin düşmesine bağlı olarak ikincil uzun ünlülerin bölge ağzında ortaya çıtığı tespit edilmiştir.

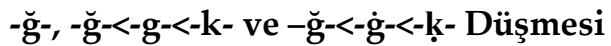

ya:ni sizin nerden bu işi gavradı:ñızı sö:ledi / Yani sizin (bizim) nereden bu işi kavradı̆̆ınızı söyledi (sordu). (IE)

onu birisi bize alıvèrse çoh fena: eyi olaca:dı / Onu birisi bize alıverse çok fena iyi olacaktı. (AD)

-h- Düşmesi

ya:ni ta:minim lise mezunuydu / Yani tahminim lise mezunuydu. (YA)

yaṕtł:ınız hareket ca:illik $\operatorname{dejdim~/Yaptığınız~hareket~cahillik~dedim.~(IE)~}$

ġı evinden para goparı: düün saiplerinden alı: / Kız evinden para koparır, düğün sahiplerinden alır. (FS)

-ñ-(>-ğ-) Düşmesi

dirge: atğ1 yaba: üçü harman aleti / Dirgen, atkı, yaba üçü harman aleti. (AD)

abam onu:la o gadar oynardın ki ya:ni çoh fena mutlu olurduñ / Ablam onunla o kadar oynardım ki yani çok fena mutlu olurdum. (AD)

nẻrden gelmişmiş aba: köyü: aha:lisi / Nereden gelmişmiş abla köyün ahalisi. (AD)

-r- Düşmesi

Bölge ağzında sıkça görülen /r/ düşmesi, genellikle geniş zaman kip eki -r ve üçüncü çokluk şahıs eki-lAr'da görülmektedir. Bunun yanında, +1Ar çokluk eki, -yor şimdiki zaman kip eki ve bazı kelimelerin kök ya da gövdelerinde de bu ses olayına rastlanmaktadır. /r/ düşmesi daha çok kelime sonunda olmakla birlikte, kelime içinde görüldüğü örnekler de vardır.

ahşama ġada: o ġiyafetlerle duru:du / Akşama kadar o kiyafetlerle dururdu. (AD)

özel gavu:ma yapılı: / Özel kavurma yapılır. (AD)

şö:le elinñe silkeleñi: / Şöyle elinle silkelenir. (FS)

bozuh para atalla: / Bozuk para atarlar. (AD)

köyümüzde bir tane drahdö: yoh / Köyümüzde bir tane traktör yok. (YA)

gel şurya otu: / Gel şuraya otur. (FS)

sene bin doḳuz yüz doḱsanlı yılla:da market̉ işine başladıḱ / Sene bin dokuz yüz doksanlı yıllarda market işine başladık. (IE)

işde yastıḳla: mutfaḱda yėmek yaṕdı̋mız yerde yığılıydı / İşte yastıklar mutfakta yemek yaptığımız yerde yığılıydı. (FS)

dimek ki fark oluyo: / Demek ki fark oluyor. (YA) 


\section{-v- Düşmesi}

Derlediğimiz metinlerde bir örnekte /v/ ünsüzünün düştügü tespit edilmiştir.

düünde pila: dağıdılı: öncü ö:lü idi / Dügünde pilav dağıtılır. Önce öyle idi. (MD)

-y- Düşmesi

Genellikle şöyle, böyle, öyle, şey, gayrı gibi sözcüklerde görülen /y/ düşmesi derlediğimiz metinlerdeki bazı örneklerde varlığını korurken, bazı örneklerde düşmüş, bazı örneklerde de tamamen düşmemiş ancak telaffuzu çok zayıflamıştır.

şö:le eliñne silkeleni: kenara oraya yerine gonu:du / Şöyle elinle silkelenir, kenara oraya yerine konurdu. (FS)

ya:ni şe asgerde ben çavuşu:dum / Yani şey askerde ben çavuştum. (IE)

çoh fazla şey olmamış / çok fazla şey olmamış. (AD)

-z- Düşmesi

çamaşı: yıhanan yere ne deni:di ġı: / Çamaşır yıkanan yere ne denirdi $k \mathfrak{k z}$. (AD)

Arapçadan Alıntı Kelimelerde Ayn $(\varepsilon)$ Ünsüzünün Düşmesi

ta:bi: bir tane şey geldi bi çavuş / Tabi bir tane şey geldi bir çavuş. (<Ar. tâbi ${ }^{\prime}$ ) (iE)

a:det öyleydi / Âdet öyleydi. ( <Ar. 'âdet) (FS)

2.1.2.2. Hece Kaynaşmasıyla Oluşan İkincil Uzun Ünlüler

\section{-f- Erimesi}

sizede gèdelle: demi musta: / Sizde de giderler değil mi Mustafa? (YA)

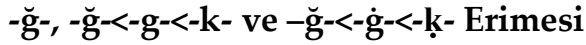

üs beş çeşit elbise alını:dı yazlıh̆ ḱışlıh̆ soḳa: giderken / Üç beş çeşit elbise alınırdı yazlık kışlık sokăga giderken. (İE)

ameriha ırağı işgal eft tìnde katil buş dèye formasını çıhardı / Amerika Irak'ı işgal ettiğinde katil Bush diye formasını çıkardı. (YA)

-h- Erimesi

valla: teyzemiziñ ġıı aynı maalledeydik / Vallahi teyzemizin kızı aynı mahalledeydik. (YA)

oñnan so:ra bu sefer niḳa: gediliyor belediyeye / Ondan sonra bu sefer nikaha gidiliyor belediyeye. (İE)

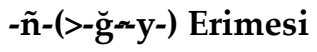

messi da: gendi: ganıdla:madı / Messi daha kendini kanıtlayamadı. (YA)

-r- Erimesi

getmen gereken yelle: iki bin beşde yène otobüs ile şeye geddiñ / Gitmem gereken yerlere iki bin beşte yine otobüs ile şeye gittim. (YA)

-y- Erimesi

cumayı cumartesiye bağla:n gece oğlan evünde oğlan arḱadaşları şe yapallar yemek

yeller / Cumayı cumartesine bağlayan gece oğlan evinde oğlanın arkadaşları şey yaparlar yemek yerler. (IE)

oğlan evüne el öpme: gederdi / Oğlan evine el öpmeye giderdi. (FS)

Arapçadan Geçen Kelimelerde Ayn ( $\varepsilon$ ) Ünsüzünün Erimesi

asgere getmeden önce şe yaṕtı́k onu durdurduḱ fa:liyeti / Askere gitmeden önce şey yaptık onu durdurduk faaliyeti. (< Ar. fa aliyet) (IE)

2.1.2.3. Türkçenin Tarihî Dönemlerindeki Ses Olaylarının İzlerini Taşıyan İkincil

\section{Uzun Ünlüler}

Bölge ağzında tespit edilen Türkçe kelimelerdeki ikincil uzun ünlülerin çoğu oluşum sürecini tamamlamamış ve ünsüz düşmesi ya da hece kaynaşması gibi ses olaylarına bağlı 
olarak meydana gelmiştir. Fakat yirmi (<yigirmi) sayısı ve -yor (-A yorır) şimdiki zaman ekinde görülen ikincil uzun ünlüler, Türkçenin tarihî dönemlerinde meydana gelmiş ve oluşumunu tamamlamış ses olaylarının izlerini taşımaktadır (Küçükballı-Yastı 2014: 462). zaten yi:rmi ayıdı seksen üçde asgerlik / Zaten yirmi aydı seksen üçte askerlik. (YA) ben bili:yoruñ / Ben biliyorum. (MD)

\subsubsection{Yabancı Dillerden Alınan Kelimelerdeki Asli Uzun Ünlüler}

Bölge ağzında yabancı dillerden geçen kelimelerdeki asli uzunlukların genellikle korunduğu tespit edilmiştir. asgerlik ḱ ḱya:feti aldı:dan so:na asgerlik başladı / Askerlik kıyafetini (<Ar. kıya:fet) aldıktan sonra askerlik başladı. (IE)

bi taḱım zi:ynet şeyleri taḱar / Bir takım ziynet (<Ar. zi:net) şeyleri takar. (FS)

\subsection{3. İkiz Ünlüler}

Bir gramer birliğinde iki vokalin yan yana gelmesi demek olan bu hadise Türkçede çok nadir olup aradaki konsonantın erimesi neticesinde ortaya çıkabilir (Ergin 1998: 52). İkiz ünlüler, iki ayrı ünlünün aynı nefes baskısı altında telaffuz edilmesiyle oluşur (Üçok 1951: 91). Bu ses hadisesi Huğlu ağzında genellikle / $\breve{g} /, / \mathrm{h} /, / \tilde{\mathrm{n}} /, / \mathrm{y} /$ seslerinin erimesine bağlı olarak ortaya çıkmıştır. Ancak şimdiki zaman kip eki -yor'dan önce gelen fiillerin geniş ünlüleri, yerlerini dar ünlülere bırakması gerekirken dar ünlülerle yan yana telaffuz edildikleri örnekler de tespit edilmiştir.

-ğ-, - $\breve{\mathrm{g}}-<-\mathrm{g}-<-\mathrm{k}-\mathrm{ve}$ - $\breve{\mathrm{g}}-<-\mathrm{g}-<-\mathrm{k}-$ Erimesi

ormannarı görüyorsun dẹil mi / Ormanları görüyorsun değil mi? (YA)

çoh öyle gayda deer bi meyve zebze oluşmaz souh geḉdii için / Çok öyle kayda değer bir meyve sebze oluşmaz soğuk geçtiği için. (YA)

düün varımış köyde / Dü̈̆̈̈̈n var imiş köyde. (AD)

-h- Erimesi

hocalar mạallenin şeyleri öylen camiden çıka: / Hocalar mahallenin şeyleri öğlen camiden çıkar. (AD)

yaṕtı̉ınız hareket caillik dėdim / Yaptığınız hareket cahillik dedim. (IE)

-ñ- Erimesi

yénge dèdi ne bişi: dẻdi baa / Yenge dedi ne pişiyor dedi bana. (MD)

neyise düürlük bitti / Neyse dünürlük bitti. (MD)

sąa da toṕ deymesse dizerike:... / Sana da top değmezse dizerken... (FS)

-v- Erimesi

dibegde döülürdü / Dibekte dövülürdü. (FS)

-y- Erimesi

köün içinde düdük çalaraḱ dolanılı: / Köyün içinde düdük çalarak dolanılır. (AD)

Şimdiki Zaman Kip Eki -yor'dan Önce Gelen Geniş Ünlülü Fiillerin Dar Ünlülerle Yan Yana Telaffuz Edilmesi

dil ağzıma sığmaıyor demiş / Dil ağzıma sığmıyor demiş. (YA)

\subsection{4. Ünlü Uyumları}

2.1.4.1. Kalınlık-İncelik Uyumu (Büyük Ünlü Uyumu)

Kalınlık-incelik uyumu, yalın veya eklerle uzatılmış Türkçe veya Türkçeleşmiş bazı alıntı kelimelerde, ilk hecedeki ünlünün taşıdığı kalınlık incelik niteliğinin ondan sonraki hecelerde de yer alması kuralıdır. Aslında bu kural Türkçe sözlerdeki kök hece ünlülerinin öteki hece ünlülerine yaptıkları etkiye göre ortaya çıkan bir benzeşme sistemidir (Korkmaz 2003: 51, 229). Büyük ünlü uyumunun yörede de genellikle korunduğunu söyleyebiliriz. 
Fakat standart dilde olduğu gibi bazı ekler ve kelimelerin bölge ağzında da uyum dışı olduğu görülmektedir.

\subsubsection{1.}

-yor şimdiki zaman eki ve bu ekin varyantları standart dildeki gibi uyum dışı olarak kullanılmaktadır. anam da verme:yceñ dèyoru: / Anam da vermeyeceğim diyor. (MD)

birbilleriñi beeniyolarsa ḱı isteme: gidiyolardı / Birbirlerini beğeniyorlarsa kız istemeye gidiyorlardr. (IE)

yere düşmeden alabilirseñ sen gazaniysiñ / Yere düşmeden alabilirsen sen kazanıyorsun. (FS)

\subsubsection{2.}

Fazla olmamakla birlikte, standart dilde uyuma girerek kullanılan bazı kelimelerin yöre ağzında uyum dışı kullanıldıkları da görülmektedir.

merdivan inerken dikkkat' edeceñ dèdi / Merdiven (Far. Nerduba:n) inerken dikkat edecen dedi. (YA)

ga:ri o al atıldıhdan so:ra yemek bişiyor / Gayrı o al atıldıktan sonra yemek pişiyor.

\subsubsection{3.}

Alıntı kelimelerin büyük çoğunluğunun uyuma girmediği görülmektedir.

köyümüzde bir tane dragdö: yoh /Köyümüzde bir tane traktör(<Fr. tracteur) yok.

növale delle: / Nevale (<Ar. neva:le) derler. (AD)

2.1.4.2. Standart Türkiye Türkçesinden Farklı Olarak Yöre Ağzında Kalınlık-İncelik Uyumuna Uyan Ekler

Türkiye Türkçesi yazı dilinden farklı olarak bazı eklerin yöre ağzında uyuma girdikleri tespit edilmiştir.

\subsubsection{1.}

+ki aitlik eki yöre ağzında uyuma girmektedir.

óbür bölüünkünü çal da gel dèdi / Öbür bölïğü̈nkini çal da gel dedi. (IE)

dağdaḳı dağ eri: / dağdaki dağ eriği (AD)

2.1.4.2.2.

Standart dilde sürekli ince ünlülü şekli kullanılan ve kalın ünlülü kelimelere eklendiğinde uyum dışı kalan -ken zarf fiil ekinin yöre ağzında çoğunlukla uyuma girdiği görülmektedir.

ġı̈g̈ır da ben çocuhksa çıhdı / Gırgır da ben çocukken çıktı. (FS)

on iki yaşındayḱa radyodan diñnerdik / On iki yaşındayken radyodan dinlerdik. (YA)

2.1.4.2.3.

- $i$ fiilinin düşürülmeden kullanıldığı yerlerde de dil benzeşmesi sonucu bu fiilin uyuma girdiği tespit edilmiştir.

telefon yoġudu / Telefon yok idi. (FS)

çobanıdı mersinli bi arhadaş / çoban idi Mersinli bir arkadaş. (YA)

2.1.4.2.4.

Standart dilde ayrı yazıldığında uyum dışı olarak kullanılan "ile" edatı da yöre ağzında uyuma girmektedir.

toḱmahıla dövelle:di / Tokmak ile döverlerdi. (IE)

daşı dize: topula yıka: / Taşı dizer top ile yıkar. (FS) 


\subsubsection{5.}

Standart dilde uyuma girmeyen bazı kelimelerin yöre ağzında uyuma girdikleri görülmektedir.

on bir tane gardaşız bö:le / On bir tane kardeşiz böyle. (AD)

tamamen cıvar köylere dişa dayalı / Tamamen civar (<Ar. civa:r) köylere dışa dayalı. (YA)

\subsubsection{Düzlük-Yuvarlaklık Uyumu (Küçük Ünlü Uyumu)}

Batı Türkçesinin son dönemlerinde sağlam olarak ortaya çıkan küçük ünlü uyumu Türkiye Türkçesinde belirli bir şekilde hüküm sürmektedir. Diğer Türk şivelerinde bu uyum sağlam bir konuma sahip değildir (Ergin 1998: 72). Bir kelimenin ilk hecesinde düz ünlü varsa sonraki hecelerde de düz, yuvarlak bir ünlü varsa sonraki hecelerde ya düz-geniş ya da dar-yuvarlak ünlülerin bulunması olayına küçük ünlü uyumu denir. Bölge ağzında da bu uyumun güçlü olduğu görülmektedir.

sıhıı̧̧ırıyorsuñ bezule barıdı / Sıkıştırıyorsun bez ile barutu. (YA)

özel yaṕdırılırdı pamılndan / Özel yaptırılırdı pamuktan. (FS)

sabın oyudu / Sabun oydu. (AD)

to:uh bişe: / Tavuk pişer. (EK)

Ancak standart dilde bu uyuma aykırılık gösteren bazı kelimelerin yörede de aykırılık gösterdiği belirlenmiştir.

ḳonya oyun havaları meşur / Konya oyun havaları meşhur. (IE)

radyo bile çoh lüks aletidi / Radyo bile çok lüks alet idi. (YA)

Yöre ağzında, kelime içindeki bazı düz ünlülerin /v/ sesinden sonra yuvarlak ünlüye dönüştüğü, böylece düzlük-yuvarlaklık uyumuna aykırılık gösterdiği görülmektedir.

oğlan evüñe el öpme: gederdi / Oğlan evine el öpmeye giderdi. (AD)

avculardan isdenirdi / Avcılardan istenirdi. (FS)

Şimdiki zaman eki -yor da düzlük-yuvarlaklık uyumuna girmez.

ḱaşlarını falan birleşdiri:yorsuñ / Kaşlarını falan birleştiriyorsun. (EÖ)

nika: gèdiliyor / Nikaha gidiliyor. (İE)

\section{2. Ünsüzler}

\subsubsection{Damak/n/'si (ñ ünsüzü)}

Türkçede üç nazal konsonant vardır. Bunlardan biri de ñ'dir. Bu sesin teşekkülünde hava geniz yoluyla çıkar (Ergin 1998: 48). Türkiye Türkçesinde standart dilde kullanılmamasına rağmen Türkçenin en eski yazılı belgelerinde bile karşımıza çıkan damak /n/ sesi Anadolu ağızlarında da yaygın bir biçimde kullanılmaktadır. Çalışmamıza konu olan Huğlu kasabasında da bu sesin yaygın bir biçimde kullanıldığı görülmektedir.

2.2.1.1. /ñn/ Sesinin Tarihî Dönemlerdeki İşlevine Yakın Olarak Kullanıldığı Bazı Örnekler Şöyledir:

2.2.1.1.1. Kelime kök veya gövdelerinde

valla: işde gadıñna toplanır esgiden / Vallahi işte kadınlar toplanır eskiden. (FS)

ḱrom işleriñi añnatinca tüfekllikֵde iş biraz şe $\mathrm{e}^{\mathrm{y}}$ yaṕtı / Krom işlerini anlatınca tüfekçilikte iş biraz şey yaptı. (IE)

2.2.1.1.2. Zamir kökenli ikinci şahıs eklerinde

patates bulgu: salça heṕsini birliǩde bişiri:siñ / Patates, bulgur, salça hepsini birlikte pişirirsin. (AD)

toṕu vuru:suñ deyeñ yana: / Topu vurursun değen yanar. (FS) 


\subsubsection{3. İyelik kökenli ikinci şahıs eklerinde}

toṕ deydi ya yıḱkılırdıñ başdan alırdıñ / Top değdi ya yıkılırdın baştan alırdın. (FS)

gelin olaca:ını bildiñ mi var ġızım sağlıḱıla / Gelin olacağını bildin mi var kızım sağlık ile. $(\mathrm{AD})$

\subsubsection{4 İkinci çokluk şahıs emir ekinde} geliñ gediñ güreş zamanı deyil / Gelin gidin güreş zamanı değil. (YA)

\subsubsection{5. İkinci şahıs iyelik eklerinde}

şö:le alırdın şu avıcıña topla:dın /Şöyle alırdın şu avucuna toplardın. (FS)

2.2.1.1.6. İlgi hâli ekinde

ilk vardı̋mda bizi niza:meniñ içerisine aldıla:r / İlk vardığımızda bizi nizamiyenin içerisine aldılar. (İE)

o bohḉanıñ ağzına da altına da para ġonu:du / O bohçanın ağzına da altına da para konurdu. (AD)

2.2.1.1.7. Yönelme ve Belirtme hâli eki almış şahıs ve işaret zamirlerinde

cığġılı derdik oña şö:le küçüküçüu_daş beş dane. / Ciggılı derdik ona şöyle küçük küçük taş beş tane. (FS)

memed efendi dėdim buña gülelle: / Mehmet Efendi dedim buna gülerler. (MD)

ya:ni oñu birisi bize alıvèrse çoh fena: eyi olaca:dı. / Yani onu birisi bize alıverse çok fena iyi olacaktı. (AD)

2.2.1.2. $/ \mathrm{g} /, / \dot{\mathrm{g}} /, / \mathrm{k} /$, / $\mathbf{k} /$ patlayıcı damak ünsüzlerinden önceki $/ \mathbf{n} /$ ünsüzünden oluşan ikincil / /n/ sesi (MD)

öğretmen geldi yėñge dedi ne bişi: baa / Öğretmen geldi yenge dedi ne pişiyor bana.

tüfegciligden önce de marañgozluh gă̆nı tekerleri öküz gağnıları burda meşurmuşmuş. / Tüfekçilikten önce de marangozluk kağnı tekerleri öküz kağnıları burada meşhurmuş. (YA)

\subsection{Ses Olayları}

Bu bölümde, derlenen metinler eş zamanlı olarak inceleneceği için tamamlanmamış ses olayları üzerinde durulacaktır. Dolayısıyla değişim yerine nöbetleşme terimini kullanmak daha doğru olacaktır. Nöbetleşme, anlam ayırıcı, anlam değiştirici veya işlev farklılaştırıcı olmayan dil birimleri değişkenlerinin birbirlerinin yerine kullanılmasıdır (Karaağaç 2015: 84)

\subsection{1. Ünlülerle İlgili Ses Olayları}

\subsubsection{1. Ünlü Nöbetleșmeleri}

Ünlü nöbetleşmesi yöre ağzında fazlaca görülmektedir. Tespit edebildiğimiz ünlü nöbetleşmelerini şu şekilde gösterebiliriz:

-a- -e-

merdivan inerken dikkat edecen dedi / Merdiven inerken dikkat edeceksin dedi. (YA)

-a- -u-

o zumanla: evler bö:le kerpiḉ felan deyildi / O zamanlar evler böyle kerpiç filan değildi. (IE)

esgiden dörd bėş odu yoġudu / Eskiden dört beş oda yoktu. (FS)

onu: bubası geldi / Onun babası geldi. (GT)

-e- - ö-

yėyecek getiri: fındıh fısdıh nö:vale delle: / Yiyecek getirir, fındık, fıstık nevale derler. (AD) 
-e- - ü-

dünya yörüngüden çıhdı / Dünya yörüngeden çıktı. (YA)

-1- -u- / -i- - ̈̈-

İçerisinde /v/ sesi bulunan bazı kelimelerde bu sesin etkisiyle /v/'den sonra gelen /1/ veya /1/ ünlüsünün /u/ veya /ü/'ye dönüştüğü tespit edilmiştir. İçerisinde /v/ sesinin olmadığı bazı kelimelerde de bu nöbetleşmenin meydana geldiği görülmüştür.

yemek verili: dışardan gelen müsafillere / Yemek verilir dışarıdan gelen misafirlere.

avculardañ isdenirdi / Avcılardan istenirdi. (FS)

devürsü:n olu: / Devirsi gün olur. (EK)

el dübeyinde onda döve:sin / El dibeğinde, onda döversin. (AD)

-i- -e-

bürgü geyer gelin / bürgü (atk1) giyer gelin. (İE)

en peşman olduğum şeylerden biri / En pişman olduğum şeylerden biri. (YA)

-i- -ö-

ġurudulmuş böber so:ạ heṕsini birlik̦de gaynadır / Kurutulmuş biber, soğan hepsini birlikte kaynatır. (AD)

-o- -u-

dohdur oranı̃̃ dolması lazım dedi / Doktor oranın dolması lazım dedi. (YA)

hanımın gelinlik fotu:rafı yoh / Hanımın gelinlik fotoğrafı yok. (YA)

-ö- -ó-

Bazı kelimelerin ilk hecesinde bulunan /ö/ ünlüsünün, yarı art ünlü olan /ó/ ünlüsüne dönüştüğü görülmektedir.

bó:le yapacahsın dediler / Böyle yapacaksın dediler. (IEE)

ḱaşını gózünü çızdı / Kaşını gözünü çizdi. (AD)

-u- -1-

özel yaṕdırılırdı pamıh̆dan / Özel yaptırılırdı pamuktan. (FS)

içine barıdı̃̃ ç̧ıbı̀gıla sıhışdırıyorsun / İçine barutunu çubuk ile sıkıştırıyorsun. (YA)

namlınıñ içini... / namlunun içini... (İE)

-u- -ö-

böyün derebuca:da vardı / Bugün Derebucak'ta vardı. (HA)

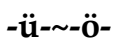

biri dasdar ${ }^{1}$ almış fena gözel / Biri dasdar almış fena güzel. (AD)

-ü- -ú-

İlk hecesinde /ü/ ünlüsü bulunan bazı kelimelerde bu /ü/'nün yarı art ünlü olan /ú/'ya dönüştüğü tespit edilmiştir.

Baḱḱaliye dúksķanı veya toplu taşıma esşi /Bakkaliye dükkânı veya toplu taşıma işi. (İE)

\subsubsection{2. Ünlü Türemeleri}

-ø- -i-(i-)

Kelime başında "ileyende" sözcüğünde görülürken, kelime içinde "neyise" ve "moderin" kelimelerinde bu ses olayına rastlanmıştır.

soyuh suyu dolduru:ḱ ileyene... / Soğuk suyu doldururduk leğene... (AD)

neyise rahme:tli bahiymiymiş / Neyse rahmetli bakıyormuş. (MD)

bisiklet çoh moderin bişeydi / Bisiklet çok modern bir şeydi. (YA) 
$-\boldsymbol{\varnothing} \sim-\mathbf{u}$

Şimdiki zaman kip ekinin 3. teklik kişi çekiminde bazen "-yor"un sonunda bir "-u" sesi türemektedir.

anam da bire verme:yceñ dėyoru / Anam da bir yere vermeyeceğim diyor. (MD)

nasıl razı olurdunuz evveli diye şey yaṕıyoru / Nasıl razı olurdunuz evveli diye şey yapıyor. (FS)

\subsection{2. Ünsüzlerle İlgili Ses Olayları}

\subsubsection{1. Ünsüz Nöbetleşmeleri}

-ç- -ş-

Süreksiz bir ses olan /ç/ ünsüzü, kelime içerisinde veya sonunda bazen yerini sürekli bir ses olan /ş/'ye bırakmaktadır.

üş noḱtada üşkַen hedefe isabet’ ettïirdik / Üç noktada üçgen hedefe isabet ettirdik. (IE) şindi yirmi yaşını geşti / Şimdi yirmi yaşını geçti. (YA)

-

soyuh suyu dolduru: / Soğuk suyu doldurur. (AD)

istekssizliknden deyil / İsteksizlikten değil. (FS)

$-\mathrm{k}-\sim-\mathrm{t}-$

Bir örnekte tespit edilmiştir.

etmek yenilirdi / Ekmek yenilirdi. (IE)

-s- -z-

Yöre ağzında birçok kelimede görülen ünsüz nöbetleşmesidir.

zabahlara gada: çalışı:dı / Sabahlara kadar çalışırdı. (HA)

herkez bi avuḉ yer ondan / Herkes bir avuç yer ondan. (AD)

öyle gayda deyer bi meyve zebze oluşmaz / Öyle kayda değer bir meyve sebze oluşmaz. (YA)

-y- -h-

ondan so:na cehizde bi sürü: iş işde / Ondan sonra çeyizde bir sürü iş işte. (FS)

\subsubsection{Sedalılaşma}

Sedasız /ç/, /f/, /k/, / / /, /p/, /s/, /ş/, /t/ ünsüzlerinin yerlerini sırasıyla sedalı karşılıkları olan /c/, /v/, /g/, /g /, /b/, /z/, /j/, /d/ ünsüzlerine bırakmasına sedalılaşma denir. Bu durum söz konusu seslerin teşekkül noktalarının aynı yerde olmasındandır (Ergin 1998: 46). Sedalılaşmayı ön, iç ve son seste olmak üzere üç grupta değerlendirmek gerekir.

\subsubsection{1. Ön seste Sedalılaşma}

Anadolu ağızlarının genelinde olduğu gibi yöre ağzında da ön seste sedalılaşma yaygindir.

zoḱahda deyyi:n deyor / Sokakta deyin diyor. (FS)

bi daş ucunda da şö:le bi tel yapışı̧hdı / Bir taş ucunda da şöyle bir tel yapışıktı. (AD)

işde ö:le guzum / İşte öyle kuzum. (MD)

\subsubsection{2. İç ve Son Seste Sedalılaşma}

Kelime sonunda bulunan süreksiz ve sedasız ünsüzlerin ünlüyle başlayan bir ek aldıkları zaman sedalılaşması standart dilde kullanılan genel bir kuraldır. Bu durum Anadolu ağızlarında da geçerlidir. Fakat hece ve kelime sonlarında bulunan bu ünsüzler genellikle ya sedalıdır ya da yarı sedalıdır. Kendinden önce ünsüz bulunan hece başlarındaki süreksiz, sedasız ünsüzler de tamamen sedalıdır.

doğumu yaşlı ebeler evde yabdırırdı / Doğumu yaşlı ebeler evde yaptırırdı. (YA)

ġtlıh̆ varmış fakirlig varmış / Kıtlık varmış fakirlik varmış. (AD) 


\subsubsection{3. Ünsüz Benzeşmeleri}

Bir dil birimindeki seslerin çıkış yeri ve çıkış biçimi bakımından birbirine yaklaşmasına benzeşme denir (Karaağaç 2015: 65).

Yöre ağzında yaygın olarak görülen benzeşmeler şunlardır:

\subsection{Gerileyici Ünsüz Benzeşmeleri}

Bir ünsüzün kendisinden önceki bir ünsüzü tamamen ya da bir özelliği bakımından kendisine benzetmesine gerileyici ünsüz benzeşmesi denir (Demir-Yılmaz, 2012: 179).

-md- -nd-

Şimdi zarfının yöredeki varyantlarında diş ünsüzü olan -d-'nin etkisiyle geniz ve dudak ünsüzü olan -m-; diş sesi olan -n- ünsüzüne dönüşmüştür.

buranıñ şindi a:detleri deyişdi / Buranın şimdi adetleri değişti. (MD)

şindi yirmi yaşını geşti / Şimdi yirmi yaşını geçti. (YA)

-ln- -nn-

Bölge ağzında yalnız kelimesinin bazen yannız biçiminde kullanıldığı görülmektedir. Bir geniz sesi olan $-n$ - kendisinden önce gelen $-l$ - sesini bazen kendisine benzeterek $-n$ - $^{\prime} y e$ dönüştürmektedir.

yannız bu mantarla ilgisi yohdur / Yalnız bu mantarla ilgisi yoktur. (YA)

-rl- -11-

Kelime içindeki $-\mathrm{l}-$ sesi, kendisinden önce gelen $-r-$ seslerini kendisine benzetmektedir.

dışarı ḳoyuyolla: / Dışarı koyuyorlar. (EÖ)

kesibiç̧i delle:di / Kesibiçi derlerdi. (AD)

bitirelim bu eş̧i delle: / Bitirelim bu işi derler. (HA)

-zs- -ss-

sạa da toṕ deymesse dizerike: toṕ deydi ya yıḳılırdıñ / Sana da top değmezse dizerken, top değdi ya yıkılırdın. (FS)

\subsubsection{2. İlerleyici Ünsüz Benzeşmeleri}

Bir ünsüzün kendinden sonra gelen bir ünsüzü tamamen ya da bir özelliği bakımından kendisine benzetmesine ilerleyici ünsüz benzeşmesi denir (Demir ve Yılmaz 2012: 179).

\section{$\dot{\mathbf{g}}(<\mathbf{k}-)-\mathbf{k} \sim \dot{\mathrm{g}}-\mathbf{b}$}

Bu benzeşme kazak kelimesinde görülmektedir. İlerleyici uzak benzeşmeyle bu sözcük genellikle ġazah şeklinde telaffuz edilmektedir.

işde ġazah örülürdü / İşte kazak örülürdü. (FS)

-ñl- -ñn-

anla-, dinle- gibi bazı kelimelerde bulunan nazal $n$, kendinden sonra gelen $-l$ - sesini kendisine benzetmektedir.

añnamı ne bilmeyoruñ / Anlamı ne bilmiyorum. (AD)

radyodan diñnerdik / Radyodan dinlerdik. (YA)

-nl- -nn-

Kelime içindeki -n- sesinin kendisinden sonra gelen -l- sesini kurallı bir biçimde kendisine benzettiği görülmektedir.

onnar geride galdı / Onlar geride kaldı. (İE)

bunna: kúccúk şu èki yaşındaydı / Bunlar küçük şu iki yaşındaydı. (MD)

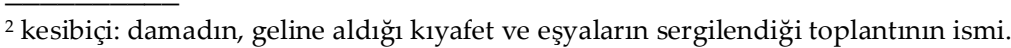


-nd- -nn-

Son sesinde -n- bulunan kelimelere ayrılma hâli eki getirildiğinde, ekin başındaki -dsesi kurallı bir şekilde -n-`ye dönüşmektedir.

o yönnen doğuya his getmedim / O yönden doğuya hiç gitmedim. (YA)

onnan so:ra ġınaya gèdilirdi / Ondan sonra kınaya gidilirdi. (AD)

\subsubsection{4. Ünsüz Düşmeleri}

\section{-f- - Ø-}

çift ve yufka kelimelerinde tespit edilen karakteristik bir ünsüz düşmesidir.

öküz gağnıları vardı on beş yirmi çit / Öküz kağnıları vardı on beş yirmi çift. (YA)

üḉ gün yuḱa yapılı:dı / Üç gün yufka yapılırdı. (GT)

-h- -ø-

Uzun ünlülerden sonra gelen -h- seslerinin genellikle düştüğü görülmektedir.

yaṕtı̉ınız hareket ca:illik dėdim / Yaptığınız hareket cahillik dedim. (IE)

düün sa:iplerinden alı: / düğün sahiplerinden alır. (AD)

-1- -Ø-

Nasıl sözcüğünün sonundaki -l-'nin bazen düştüğü görülmektedir. İlerleyici ünsüz benzeşmesine uğrayan anla- ve dinle- fiillerindeki -l- sesi de bazen düşmektedir. Altmış ve kalk- sözcüklerindeki-l- de bölgede düşmektedir.

nası deyyiñ / Nasıl diyeyim? (EK)

bö:le ana:dıyoñ / böyle anlatıyorum. (FS)

radyodan di:nenirdi / Radyodan dinlenirdi. (YA)

bizi dö:me: ḱahdı / Bizi dövmeye kalktı. (İE)

bin doġuz yüz atmış ihtilaline ġadar... / Bin dokuz yüz altmış ihtilaline kadar... (YA)

-n- -Ø-

Genellikle -ken zarf-fiil ekinde görülen bir ses düşmesidir. İlgi ekinin sonunda bulunan -n- ünsüzü de bazen düşmektedir. Bunun yanında dünür kelimesindeki -n- sesinin de çoğunlukla düştüğü görülmektedir.

ohula gederkede uğra:dıḱ / Okula giderken uğrardık. (AD)

neyise düürlük bitti / Neyse dünürlük bitti. (MD)

onu:la da haber getiriyo: / Onunla da haber getiriyor. (FS)

-r- -ø-

Kendisinden önceki ünlünün, uzun ünlüye dönüşmesiyle geniş zaman ekindeki -r ünsüzünün çoğunlukla düştüğü görülmektedir.

yüzük taḱkılı: / Yüzük takılır. (EÖ)

üzümle: yıḱanı: / Üzümler yıkanır. (EK)

esgiden bi evde dört' gelin duru:du / Eskiden bir evde dört gelin dururdu. (HA)

"Sonra" kelimesinin ilk hecesindeki ünlünün uzun olduğu durumlarda da bazen -r ünsüzü düşmektedir. "Bir" kelimesinin sonundaki $-r$ de bölge ağzında genellikle düşürülmektedir.

ondan so:ña galhan a:detlerden $u_{\text {nduz }}^{3}$ da va: / Ondan sonra kalkan adetlerden unduz da var. (FS)

ondan so:ña geliñ süsleni: / Ondan sonra gelin süslenir. (EÖ)

neyse bi atış alanına gèttik / Neyse bir atış alanına gittik. (İE)

zaten acelemiz yoh bi paket dạa ver demiş / Zaten acelemiz yok bir paket daha ver demiş. (YA)

${ }^{3}$ unduz: Damat kız evine içine un ve tuz konulan bir sandık götürür. Bu âdete verilen isim. 
Özellikle çokluk eki -lAr ile 3. çokluk şahıs eki -lAr'ın kullanıldığı kelimeler başta olmak üzere bazı sözcüklerde uzun ünlüden sonra gelen $-r$ seslerinin düştüğü görülmektedir.

ġıza alınañ elbisele: gösderili: / Kıza alınan elbiseler gösterilir. (AD)

ben alma: dünü: geldile: / Beni almaya dünür geldiler. (MD)

çay içėyolla: / Çay içiyorlar. (EK)

\subsubsection{Göçüşme (Metatez)}

Kelime içinde yan yana bulunan çift ünsüzlerin veya komşu hece ünsüzlerinin yer değiştirmesine göçüşme denir (Korkmaz 1994: 84). Göçüşmenin nedeni konuşmayı kolaylaştırmak için kelimedeki ünsüzlerin boğumlanma noktalarının kolaydan zora doğru sıralanmasıdır (Gülensoy 1988: 69). Derlediğimiz metinlerde bu ses olayına fazla rastlanmamıştır. Tespit edilen göçüşme olayına şu örnekleri verebiliriz.

-ğr- -rğ-

hemen hemen geriye dorğu heṕ sanat ruhu vardı köyde / Hemen hemen geriye doğru hep sanat ruhu vardı köyde. (YA)

-(k>)gş- -şg(<k)-

limon duzuynan eşgi yerine ya:ni gurudulu: / Limon tuzuyla $\boldsymbol{e} k s ̧ i$ yerine yani kurutulur. (AD)

-ny(l>)- -(1<)yn-

kesiynikle eve gėder oñu diynerdim / Kesinlikle eve gider onu dinlerdim. (YA)

-rh- -hr-

varsa oturu: yerdik yohsa tahrana gatar cebimize gederdik / Varsa oturur yerdik, yoksa tarhana koyar cebimize giderdik. (AD)

\subsubsection{6. Ünsüz İkizleșmeleri}

İç seste iki ünlü arasında bulunan bazı ünsüzlerin iki farklı heceye ait olmak şartıyla tekrarlanmasına ünsüz ikizleşmesi denir (Karaağaç 2015: 80). Talat Tekin'e göre ünsüz ikizleşmesi ile ünlü uzunlukları arasında bir ilgi vardır. Açık hecedeki uzun ünlünün çekici etkisiyle sonraki hecenin başındaki ünsüz ikizleşir. İkizleşme neticesinde ilk hece kapalı hâle gelir ve uzun ünlü kısalır (1995: 126). verebiliriz

Derlediğimiz metinlerde tespit ettiğimiz ünsüz ikizleşmelerine şu örnekleri

-c(<-ç-)- -cc-

bunña: ḱúccúk şu èki yaşındaydı / Bunlar kü̧̈ük, şu iki yaşındaydı. (MD)

-k- - -ḳk-

ya:ni sevündürici hem hüzünñendirici türküler oḳkunu: / Yani sevindirici hem hüzünlendirici türküler okunur. (IE)

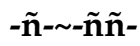

ev halḳından birisi oyaññ oyaññ sürü: / Ev halkından birisi $o$ yana o yana sürer. (AD)

-S- -SS-

essahdan(Ar.<esahh) da fark olur / Essahtan da fark olur. (YA)

-ş- -şş-

bez̧le barıdı üsdüne saşma içine fişşek oluşduruyorsun / Biz ile barutu üstüne saçma içine fişek oluşturuyorsun. (YA)

-y- -yy-

nası razı oldun anne dèyyo / Nasıl razı oldun anne diyor. (FS) 
yavruñ bilmi:yyoruñ / Yavrum bilmiyorum. (MD)

\section{MORFOLOJIKK ÖZELLIKKLER}

\subsection{Vasıta Hâli Eki}

Hâl, ismin kendi dışında kalan kelimelerle münasebetini ifade eder (Ergin 1998: 129). Vasıta hâli ismin belirttiği nesnenin vasıta olarak kullanıldığını, fiile vasıta olduğunu gösterir (Vural-Böler 2012: 151). Huğlu kasabasında vasıta hâli olarak genellikle +XlA eki kullanılmaktadır. Ancak bunun yanında +Xlan, +XnAn, +XA eklerinin de vasıta hâlini karşılamak için kullanıldığı görülmektedir.

toplu taşımacılıḱulan münübüs işletmeciliğine başladıḱ / Toplu taşımacılıkla minibüs işletmeciliğine başladık. (IE)

limon duzuynan eşgi yeriñe ya:ni gurudulur / Limon tuzuyla ekşi yerine yani kurutulur. (AD)

maradonaya hayatta giyasedilemez / Maradona'yla hayatta kıyas edilemez. (YA)

bellèk atmaḱ dèdiğimiz şeyile / Bellek atmak dediğimiz şeyle. (IE)

topula yıka: / Topla yıkar. (FS)

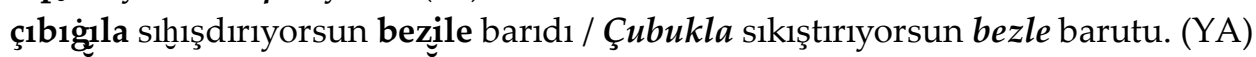

get ġızıñ sağlığlarla sil gözünü yağlığlarla ${ }^{4}$ Git kızım sağlıklarla sil gözünü yağliklarla. (AD)

\section{2. Şahıs Ekleri}

\subsubsection{Zamir Kökenli Şahıs Ekleri}

Standart Türkçede olduğu gibi yöre ağzında da duyulan geçmiş zaman, geniş zaman, şimdiki zaman ve gelecek zaman kipleriyle birlikte zamir kökenli şahıs ekleri kullanilmaktadır.

1. Teklik Şahıs: $-(X) \mathrm{m} /-(\mathrm{X}) \tilde{\mathbf{n}}$

Standart yazı dilinde kullanılan -Xm eki yörede çok az kullanılmaktadır. 1. teklik şahıs için genellikle -Xñ ekinin tercih edildiği görülmektedir.

ha şeylere bahıyom ağır siklet baharı̃ severiñ / Ha şeylere bakıyorum ağır sıklet bakarım severim. (YA)

yüzüme ėyi baḱ beni unutma deriñ / Yüzüme iyi bak beni unutma derim. (GT)

oğlanlarnı biliriñ / Oğlanlarını bilirim. (HA)

ben biliyoruñ / Ben biliyorum. (MD)

fazla da hatırlamıoñ / Fazla da hatırlamıyorum. (EK)

2. Teklik Şahıs: -sXñ / -sXn

Ekin sonundaki " $n$ ", genellikle damak " $n$ "si (ñ) olarak telaffuz edilmekle birlikte nadiren " $\mathrm{n}$ " şeklindeki kullanıma da yöre ağzında rastlanmaktadır.

toṕu vuru:suñ deyen yana: / Topu vurursun değen yanar. (FS)

oñu yağla:sıñ bö:le yaparsıñ / Onu yağlarsın böyle yaparsın. (AD)

3. Teklik Şahıs: $-\varnothing$

başḱa giysilere doğru gideyor / Başka giysilere doğru gidiyor. (IE)

yumaḱ dışarda düşmüş / Yumak dışarıda dü̈smï̈ş. (FS)

1. Çokluk Şahıs: -(X)z

şuna verecez / Şuna vereceğiz. (YA)

iñi deriz de biz / İni deriz de biz. (FS)

${ }^{4}$ yağlık: mendil

SEFAD, 2017 (38): 1-22 


\section{2. Çokluk Şahıs: -sXnXz}

bahceye geldiniz mi yörürsünüz / Bahçeye geldiniz mi yürürsünüz. (YA)

bize bóle bóle yapıyosunuz / Bize böyle böyle yapıyorsunuz. (IE)

3. Çokluk Şahıs: -1Ar / -1A:

kulhü yeme: deller / Kulhü yemeği derler. (IE)

buña: gülelle: / Bunlar gülerler. (MD)

\subsection{2. İyelik Kökenli Şahıs Ekleri}

Standart yazı dilimizde görülen geçmiş zaman ve şart kipleriyle kullanılan iyelik kökenli şahıs eklerinin, Huğlu ağzında şimdiki zaman, geniş zaman ve gelecek zaman kipleri için de kullanıldığı görülmektedir. Örneğin 1. teklik şahıs için hem iyelik kökenli hem de zamir kökenli eklerde benzer yapılar kullanılmaktadır. Diğer Anadolu ağızlarında da örneklerine rastlanan bu tür çekimlerde şahıs eklerinin iyelik kökenli mi yoksa zamir kökenli mi olduğu henüz kesinlik kazanmamıştır (Küçükballı-Yastı 2014: 475).

1. Teklik Şahıs: $-(X) \mathrm{m} /-(\mathrm{X}) \tilde{\mathbf{n}}$

Genellikle $-(X) \mathrm{m}$ şeklinde kullanılmakla birlikte bazen $-(X) \tilde{n}$ şeklinde de kullanıldığ görülmektedir.

süt sąardım satardım / Süt sağardım satardım. (MD)

ya:ni çoh fena mutlu olurduñ / Yani çok fena mutlu olurdum. (AD)

hatła vanda öğrencilere söylediñ / Hatta Van'da öğrencilere söyledim. (YA)

ben sizi bırahdım artıh dèdi / Ben sizi bıraktım artık dedi. (YA)

2. Teklik Şahıs: $-(X) \tilde{\mathbf{n}}$

İyelik kökenli ikinci şahıs eklerinde Türkçenin tarihî dönemlerindeki gibi damak /n/'sinin korunduğu görünmektedir.

eğer subay assubay olmah isderseñ / Eğer subay astsubay olmak istersen. (YA)

toṕ deydi ya yıḱkılırdıñ başdan alırdıñ / Top değdi ya yıkılırdın baştan alırdın. (FS)

bunnara ohuma yazma öğredeceñ / Bunlara okuma yazma öğreteceksin. (YA)

3. Teklik Şahıs: $\varnothing$

bohcu: kim açıyosa o para onu: olu:du / Bohçayı kim açıyorsa o para onun olurdu. (AD)

altın tahdı / Altın taktı. (MD)

1. Çokluk Şahıs: $-(X) \underline{\mathbf{k}},-(\mathrm{X}) \mathbf{k},-(\mathrm{X}) \mathbf{h}$

neyse evlendik geldik / Neyse evlendik, geldik. (MD)

birer oda paylaşırdıh / Birer oda paylaşırdık. (FS)

gederke:de uğra:dıḱ / giderken de $\boldsymbol{u}$ ğrardık. (AD)

2. Çokluk Şahıs: $-(X) \tilde{\mathbf{n}} X z$

hęç açlıh̆ çekdiñiz mi / Hiç açlık çektiniz mi? (YA)

nasıl razı olurduñuz / Nasıl razı olurdunuz? (FS)

3. Çokluk Şahıs: -1Ar / -1A:

düün aşını aldıla: / Düğün aşını aldılar. (AD)

bó:le yapacahsın dèdiler / Böyle yapacaksın dediler. (IE)

3.2.3. Emir Kökenli Şahıs Ekleri

1. Teklik Şahıs: -(X)yXñ / -i:m

ne bili:m / Ne bileyim. (AD)

annadayıñ yavruñ / Anlatayım yavrum. (MD)

3.Teklik Şahıs: -sIñ

şurdan on gişi çıا̆sı̃ñ / Şuradan on kişi çıksın. (YA) 
tavan ahmasıñ deyi... / Tavan akmasın diye... (FS)

1. Çokluk Şahıs: -AlIñ / -A:IIñ / -AlIm / -A:IIm / -AlıK

Huğlu kasabasında birinci çokluk şahıs emir eki genellikle -AlIñ / -A:IIñ, bazen de AlIm / -A:IIm'dir. Bununla birlikte nadir olarak -AlıK ekinin de çokluk birinci şahıs emir eki olarak kullanıldığı derlediğimiz metinlerde görülmektedir. Bu ekin Eski Kıpçak Türkçesine ait bazı metinlerde de çokluk birinci şahıs eki olarak kullanıldığı tespit edilmiştir. (Karamanlıŏlu 1994: 116).

bahıñ bu türḱ bayrağıñı söke:liñ / Bakın bu Türk bayrağını sökelim. (YA)

dedik ki bi ticari: hayat düşünelik / Dedik ki bir ticari hayat düşünelim. (IE)

şuraya otu: baḱalım / Şuraya otur bakalım. (FS)

2. Çokluk Şahıs: $-(X) \tilde{\mathbf{n}}$

şö:le oluñ bö:le oluñ mutlu oluñ / Şöyle olun, böyle olun, mutlu olun. (IE)

geliñ gèdiñ güreş zamanı deyil / gelin, gidin güreş zamanı değil. (YA)

3.3. Şimdiki Zaman Kipi: -yor / -yoru / -yol / -yo / -yyo / -yyor / -yur / -i / -iy

Anadolu ağızlarının sınıflandırılmasında kullanılan önemli ölçütlerden biri şimdiki zaman kip ekidir. Bu ek, ses yapısı bakımından gösterdiği çeşitlilikle Anadolu'daki ağız gruplarının tespit edilmesinde önemli bir rol oynamaktadır (Karahan 1996: XI). Ek, Huğlu ağzında da farklılık göstermektedir. Genellikle -yor ekinin farklı versiyonlarının kullanıldığı şimdiki zaman kipi için bazen -i ve -iy eklerinin kullanıldığı da görülmektedir. -yol eki çoğunlukla üçüncü çokluk şahıs eki -lAr'ın etkisiyle ortaya çıkmıştır. Ekin başındaki -lkendinden önce gelen -r- sesini kendisine benzetmiştir.

bu ağrımıyor bu ağrıyor / Bu ağrımıyor bu ă̆rıyor. (YA)

ko:mutanım dejyyoz / Komutanım diyoruz. (IE)

hèç kimse ḱarşılamıyyor / Hiç kimse karşılamıyor. (GT)

kim açıyosa o para onu: / Kim açıyorsa o para onun (AD)

uzay boşluğuna gedeyoz / Uzay boşluğuna gidiyoruz. (YA)

filan pasdanede oturuyur / Filan pastanede oturuyor. (IE)

yẻnge dèdi ne bişi: / Yenge dedi ne pişiyor. (MD)

ohu bahayıñ ohuyabili:ñ mi? / Oku bakayım okuyabiliyor musun? (HA)

rah me:tli bahiymiymiş / Rahmetli bakıyor muymuş? (MD)

sen gazaniysiñ / Sen Kazanıyorsun. (FS)

yat' deyoru / yat diyor. (HA)

şindiki çocuhlara baḱıyo:n da / Şimdiki çocuklara bakıyorum da... (AD)

gelin evünü süslüyolla: / Gelin evini süslüyorlar. (IE)

\subsection{Zarf-fiiller}

\subsection{1. -ke: -ka: -ike: -ken}

Bu ek sadece i- fiilinin zarf-fiil ekidir(Ergin, 1998: 346). Standart Türkçede tek şekilli olan ekin Huğlu ağzında, kalınlık-incelik uyumu ve ses düşmesi olayına bağlı olarak farklı kullanımları da vardır.

ohula gederke:de uğra:dıḱ gelirke:de uğra:dıḱ / Okula giderken de uğrardık gelirken de uğrardık. (AD)

esgiden harman işlenirke: tahta olu:du /Eskiden harman işlenirken tahta olurdu. (GT)

saba: ezanı oḱunu:ḳa zuḳa: çı́kııı: / Sabah ezanı okunurken sokağa çıkılır. (EK)

ilkohul bire giderken köyümüzde ceryan yohdu / İlkokul bire giderken köyümüzde cereyan yoktu. (YA) 


\section{5. Bağlaç ve Edatlar}

\subsection{1. ile 1la ula ulan}

Yalnız başlarına bir anlam taşımayan, ancak eklendikleri kelime ve kelime gruplarının yardımı ile anlam kazanabilen sözlere edat ya da bağlaç denir (Korkmaz vd., 2010: 192). Türkçede son çekim edatları birer kelime olmakla birlikte morfolojik unsur gibi kullanılabilme özelliklerinden dolayı ekleşmeye, ek olmaya çok müsaittir. Türk dili ekleştireceği herhangi bir unsuru, önce çekim edatı durumuna getirmektedir. (Buran, 2008: 155). Türkçede "ile" edatı da genellikle ekleşmiş haliyle kullanılmaktadır. Ancak Huğlu ağzında bu edatın genellikle ekleşmediği ve ünlü uyumlarına uyduğu görülmektedir.

toplu taşımacılıǩ́ulan münübüs işletmeciliğine başladıḱ / Toplu taşımacılık ile minibüs işletmeciliğine başladık. (IE)

topula yıka: / Top ile yıkar. (FS)

oğlan da sağdıçıla ġı evüne gèder / Oğlan da sağdıç ile kız evine gider. (AD)

çıbıgı̀la sıhışdırıyorsun bez̧ile barıdı / Çubuk ile sıkıştırıyorsun bez ile barutu. (YA)

3.6. Ek-eylem (Ek-fiil / Cevher fiil) “i-“

Eski Türkçede "er-“ yardımcı fiilinin er->ir->i- biçiminde ekleşmesiyle meydana gelen ad soylu sözcüklerin yüklem olarak kullanılmasını sağlayan ve birleşik fiil çekimlerinde de görev alan fiile ek-eylem denir (Korkmaz, 2003: 81). Sadece bir kısım şekil ve zaman eklerini alabilen bu fiilin bazı kipleri vardır (Ergin, 1998: 314). Tek başına bir anlamı olmayan ekeylemi Türkçede yaygın olarak kullanılır. Anadolu ağızlarında bu ek ünlü uyumuna uyarak “1-, u-“ şekillerinde de görülmektedir (Gülensoy, 2000: 420). Türkiye Türkçesi yazı dilinde genellikle düşürülen ek-eylemin, Huğlu ağzında çoğunlukla korunduğu ve ünlü uyumlarına uyduğu görülmektedir.

beyaz örtü varıdı / Beyaz örtü vardı. (IE)

yemeglerimiz çoğudu / Yemeklerimiz çoktu. (GT)

metalı bilmezike:... / metalı bilmezken... (YA)

bi gelin ohşayan ġadın varı̣mış / Bir gelin okşayan kadın varmış. (AD)

\section{SONUÇ}

Konya ili, Beyşehir ilçesi, Huğlu kasabasından derlenen metinlerden, yöre ağzıyla ilgili şu tespitlere ulaşılmıştır:

a) Türkçenin tarihî metinlerinde görülen, Türkiye Türkçesi yazı dilinde bulunmamasına rağmen birçok Anadolu ağzında varlığını sürdüren kapalı e (è) ve damak n'si (ñ) bölgede yaygın bir şekilde kullanılmaktadır.

b) Ünsüz düşmesi ve hece kaynaşması sonucu meydana gelen ikincil uzun ünlüler bölgede yaygın bir şekilde kullanılmaktadır.

c) Büyük ve küçük ünlü uyumlarının bazı istisnalar dışında güçlü olduğu görülmektedir.

d) İlerleyici ve gerileyici ünsüz benzeşmelerine bölgede sıkça rastlanmaktadır.

e) Vasıta hâli eki olarak genellikle +XIA kullanılsa da +Xlan / +XnAn / +XA biçimlerine de rastlanmaktadir.

f) Zamir kökenli 1. teklik şahıs eki olarak genellikle -(X)ñ kullanılmaktadır. -(X)m eki çok az kullanılmaktadır.

g) Şimdiki zaman kip eki çeşitlilik göstermektedir. Bu kipi karşılamak için -yor / -yoru / yol / -yo / -yyo / -yyor / -yur / -i / -iy eklerinin kullanıldığg görülmektedir.

h) Huğlu ağzında ek-eylemin yaygın olarak düşürülmeden kullanıldığı ve ünlü uyumlarına da uyduğu görülmektedir. 
i) Çalışmada Beyşehir ilçesine bağlı Huğlu kasabasının fonetik ve morfolojik özellikleri tespit edilmeye çalışılmıştır.

\section{DERLENEN METINLERDEN ÖRNEKLER}

...neyse bi atış alanına gèttik bizi tüfek atalla: hesabı yaṕınca tüfek atış̧ları tabi hemen bölük ḱ komutanı bizi görünce şe yaṕtı ya:ni siziñ nerden bu işi gavradı:nızı sö:ledi biz dèdik tüfekcciliknden nere filan filan filan huğlu ḱasabası konyaya bağlı beyşeir ilçesine bağlı bö:le bö:le garı ondan soña: kendi silahlarını bize baḱım onarım şeyine aldılar orda asgerli:mizi tamamladıḱ geldik ya:ni güzel bi ortam oldu asgerliǩte asgerlik arḱkadaşlarımızla èyi düşüncelerimiz oldu ḱomutanlar severdi bizi neden severdi en önemli şe silah üzerindeki hakimiyet bilgi beceri temizleme mesela asgeryede namlının içini karancalandığını karanca neden olduğu:nu annatınca ḱrom işlerini annatinca tüfeklliḳde iş biraz da̧a şe yaṕtı ciddiyetini ḱavrayınca biz dąa aranır eleman olmaḱ şeine gèttik

İsa ERDOĞAN

...ben alma: dünü: geldile: yėdi çocuh dėdile: anam vėrme:cekdi bẻş çocuh dẻdile: ben biliyoru:n çocuğun biri altı aylıḥıdı bunna: knúccúk şu èki yaşındaydı a:ba ben çocuğun neyise: rahme:tli bahıymiymiş benden ötürü sö:lemesi ayıṕ bahmış beni göre:memiş ben onu gö:rdüm tamam dėdim anam da bire verme:ycen yėyoru: rahme:tli ciyerdi ha:zar zormuş hocam neyse evlendik geldik eyi burya şe èttile: ba: hoş geldin dẻdi ben de hoş bulduh memed efendi dèdim buña: gülelle: çocuhla: güle: onan so:ra geldim torula: çocu:la: eyiydi:k rahmetli öldü alla: rahmet eylesin birde şurda öğretmen var benim ine:m var süt saardım satardım öğretmen geldi yėnge dėdi ne bişi: dèdi bạa: bende oña teşekkür dẻdim. bunñarı aldım dèdi...

Mahire DEMİRCi

...valla: işde gadınna: toplanır esgiden biz çocuhka: telefon yoğudu birbirine sa: oturma: gelece:ni haber etme yoğudu zabah saat dokuzda kimi ev süpürü: kimi bulaşıḱ yıkar kimi ahıra çanağa ineğe şeye inmiş olu: gapıya tıh̆ tıh vurulu: buyurun goltu:nun altında bi ip yuma: ikide miçḉaḱla: içinde üstünde gide: geli:di buyrun buyrun yoğudu orda gel baḱalım şuraya otu: baḱalım dèrdik buyurun falan yoğudu ama gayette istekssizliknden deyil şey öylėydi a:det öylėydi şey o gadarıdı yani gö:üş gel şurya otu: ayşe a:ba Fatma aba oturulu: oturudu: naparsınız hattła bazen arada bir olmaḱla yumaḱ dışarda düşmüş olurdu iṕ buraya gadar gelirdi işde ö:le yumaḩda heṕ böyle sökülmüş düümlü müümlü iṕlerden olurdu hani yeni yumah filan olmazıdı olurdu da çoh az olurdu

Fatmana SANDAL

...kesibiçi va: oğlan evi aldıhları bohcuyu alı: gėder işde gonu gomşuda toplanır ondan so:ra ortaya boḩ̧̧a getirili: işde şu ġızın birinci daḱı:mı şu iǩinci daḱı:mı ġıa alınan elbisele: gösderili: şu pijaması şu ayaḱḱabısı deyi: gösderili: o boḩcanı: şeyinde de yaḱını biri aça:dı o bohḉanıñ ağzına da altına para ġonu:du açan alır o para bohḉu kim açıyosa o para onu: olu:du. işde o toṕlantının adı kesibiḉi delle:di ġıyafete bahma günü veya kesibiḉi yapılı:dı loḱum dağıdılı:dı gẻdili: el öpme: el öṕülü: loḱum dağılı: alayoḱa dẻnirdi mantıḱca anñamı ne bilmeyoruñ ama genç ḱızın ġyafet̉leri genç ġıza alına:n ġıafetleri: ġız arḥadaşları geyeridi. èrtesi günü cumartesi günü ama esgiden bu şindi gahdı ġızın çoh yaḱın üç arḱadaşı ġıza alınan ġıyafetleri gèyer oğlan evüñe el öpme: gederdi o gün ahşama gada: o ġıafetlerle duru:du ġızın ġıafetlerini gösteri:

Ayşe DEMIRCI 
...asgeri ḱademelerde o gündeki atalarımız kurtuluş savaşı zamanñarında asgeri ḱademelerde o silah tamiri ilk bura: geldiklerinde da: metalı bilmezike: o şeyşana dedijimiz dolma tüfekller tek tüfekller fişşek deyil de içine barıdını şeyşana tüfegler çıbığıla sıhış̧ırıyorsuñ bezile barıdı üsdüne saşma içine fişşek oluşduruyorsuñ yaḱlaşıḱ yüz yıllıḱk tarịimiz var hocam yalnız bizim köyün esgiden marangozluh ya:ni öküz gağnısı o isbit tekerle: inşaad usdalığı hemen hemen geriye dorğu heṕ sanat’ ruhu vardı köyde hocam tüfegciligden önce de marangozluh ga gănı tekerleri öküz gağnıları burda meşurmuşmuş aynı tüfegcilig gibi geriye dorğu gène de malcılıh veya sadece kendi yė:ceği içece:ği için bizim otuz ḱrı́ davarımız varıdı keçimiz varıdı hemen hemen her evde olmasa da iki evden birinde büyükbbaş hayvan vardı sütünden yourdundan yararlanmak için ama şu anda davar varsa davar davar olma:nıñ da ineg olurdu hocam artıḱ son on beş yıldır bir tane büyüg ve küçükbaş hayvan yoh

Yaşar AKTAŞ

\begin{tabular}{|c|c|c|}
\hline Adı Soyadı & $\underline{\text { Yaș1 }}$ & $\underline{\text { Kisaltmas1 }}$ \\
\hline Ayşe Demirci & 50 & $\mathrm{AD}$ \\
\hline Elif Kenar & 22 & EK \\
\hline Elif Özcan & 21 & EÖ \\
\hline Fatmana Sandal & 54 & FS \\
\hline Günay Tural & 58 & GT \\
\hline Hüseyin Aslan & 80 & HA \\
\hline İsa Erdoğan & 52 & IE \\
\hline Mahire Demirci & 78 & MD \\
\hline Yaşar Aktaş & 55 & YA \\
\hline
\end{tabular}

\section{SUMMARY}

Dialectology surveys have an important place in language arts. Although the beginning of the dialectology surveys for Turkish can not be taken as clear information, we can take it to Kashgarli Mahmud. In Turkey, the dialect studies have seriously started with Ahmet Caferoglu and continued for many years in his pioneering period. Recently, one of the regions where dialect studies have been done is the town of Huğlu bound to the Beyşehir district of Konya.

Located on the south-west of Konya, approximately $130 \mathrm{~km}$ from Konya and $35 \mathrm{~km}$ from Beyşehir, is the town of Huğlu. The rifles produced in the rifle factory in the town are exported domestically and abroad. $80 \%$ of the population make their living from rifle production. The remaining part deals with trade. Because of the ruggedness of the region and the small amount of agricultural land, agriculture is less tested. There is almost no tractor in the town. Animal husbandry has been an important source of livelihood in the past few years. The region, which dates back to $70-80$ years ago, has its own dialect features. It is possible to know whether one is from Huğlu by looking at the conversation of a person in and around Beysehir. We can say that the dialect of the region reflects the language characteristics of Turkmens more.

In this study, it was attempted to determine the phonetic and morphological features of Turkmen from the standard Turkish Turkic.

The following are the findings regarding the region of Huğlu: 
* The closed e (è) and palate $n(\tilde{n})$ are widely used in the region, which are found in the historical texts of the Turkic people and which persist in their existence in many Anatolian dialects.

* Consonant falls and syllabic fusion are widely used in the secondary long prominent area from the last square.

* It seems that the great vowel harmony and small vovel harmony is strong except for some exceptions.

* Progressive and regressive consonant similarities are frequently encountered in the region.

* The instrumental is also found in the form + Xlan / + XnAn / + XA, although it is usually used with + XlA.

* The first uniqueness of the pronoun is usually used as - $(X) \tilde{n}$. - $(X) m$ is used very little.

* Present-time mode is variable. It seems that the addition of -yor / -yoru / -yol / -yo / yyo / -yyor / -yur / -i / -yy suffices to satisfy this mode.

* The phonetic and morphological characteristics of the town of Huğlu have been attempted to be determined in the study. 


\section{KAYNAKÇA}

BANGUOĞLU, Tahsin (2007). Türkçenin Grameri. Ankara: Türk Dil Kurumu Yay.

BURAN, Ahmet (2008). Makaleler. Ankara: Turkish Studies.

DEMIR, Nurettin (1996). "Ağız Araştırmalarında Kaynak Kişi Meselesi". Uluslararası Türk Dili Kurultayı (23-27 Eylül 1996). Ankara: Türk Dil Kurumu Yay.

DEMIR, Nurettin-YILMAZ, Emine (2012). Türk Dili El Kitabı. Ankara: Grafiker Yay.

ERCİLASUN, Ahmet Bican (1983). Kars İli Ağızları. Ankara: Gazi Üniversitesi Yay.

ERDEM, Mehmet Dursun-GÜL Münteha (2006). “Kapalı e (è) Sesi Bağlamında Eski Anadolu

Türkçesi-Anadolu Ağızları İlişkisi". Karadeniz Araştırmaları (11): 111-148.

ERGİN, Muharrem (1998). Türk Dil Bilgisi. İstanbul: Bayrak Basım Yayım Tanıtım.

GEMALMAZ, Efrasiyap (1999). "Ağız Bilimi Araştırmaları Üzerine Genellemeler". Ağız Araştırmaları Bilgi Şöleni (9 Mayıs 1997). Ankara: Türk Dil Kurumu Yayınları. 4-13.

GÜLENSOY, Tuncer (1988). Kütahya ve Yöresi Ağızları. Ankara: Türk Dil Kurumu Yay.

GÜLENSOY, Tuncer (1999). "Ağız Araştırmalarının Bugünkü Durumu”. Ağız Araştırmaları Bilgi Şöleni (9 Mayıs 1997). Ankara: Türk Dil Kurumu Yayınları: 16-21.

GÜLENSOY, Tuncer (2000). Türkçe El Kitabı. Ankara: Akçă̆ Yay.

KARAAĞAÇ, Günay (2015). Türkçenin Ses Bilgisi. İstanbul: Kesit Yay.

KARAHAN, Leyla (1996). Anadolu Ağızlarının Sınıflandırılması. Ankara: Türk Dil Kurumu Yay.

KARAMANLIOĞLU, Ali Fehmi (1994). Kıpçak Türkçesi Grameri. Ankara: Türk Dil Kurumu Yay.

KORKMAZ, Zeynep (1971). "Anadolu Ağızlarının Etnik Yapıyla İlgili Sorunu". TDAYBelleten: 21-32.

KORKMAZ, Zeynep (1994). Güney-Batı Anadolu Ağızları. Ankara: Türk Dil Kurumu Yay.

KORKMAZ, Zeynep (2003). Gramer Terimleri Sözlüğü. Ankara: Türk Dil Kurumu Yay.

KORKMAZ, Zeynep-ERCILASUN, Ahmet Bican vd. (2010). Türk Dili ve Kompozisyon. Bursa: Ekin Yay.

KÜÇÜKBALLI, Fatih Numan-YASTI, Mehmet (2015). “Sarayönü Yörük ve Türkmen Ağızlarının Belirgin Dil Özellikleri". Tarih, Kültür, Sanat, Turizm ve Tarım Açısından Uluslararası Sarayönü Sempozyumu. ed. Hasan Bahar. (24-26 Ekim 2014). Konya: Selçuk Üniversitesi Türkiyat Araştırmaları Enstitüsü Yayınları: 453-484.

SAĞIR, Mukim (2002). "Ses Olayları Bakımından Anadolu Ağızları". Atatürk Üniversitesi Türkiyat Araştırmaları Enstitüsü Dergisi (20): 1-7.

TEKİN, Talat (1995). Türk Dillerinde Birincil Uzun Ünlüler. Ankara: Simurg Yay.

TOPALOĞLU, Ahmet (1989). Dil Bilgisi Terimleri Sözlü̈̆̈̈̈. İstanbul: Ötüken Neşriyat.

ÜÇOK, Necip (1951). Genel Fonetik. İstanbul: İbrahim Horoz Matbaası.

VURAL, Hanifi-BÖLER Tuncay (2012). Ses ve Şekil Bilgisi. İstanbul: Kesit Yay.

YAVUZ, Orhan (1991). “Türkçede Kapalı E”. Selçuk Üniversitesi Fen-Edebiyat Fakültesi Edebiyat Dergisi (6): 271-306.

YILMAZ, Emine (1991). “Ana Türkçede Kapalı e Ünlüsü”. Türk Dilleri Araştırmaları: 151-156. 